ETO: 821.511.141.BABITS M1

ORIGINAL SCIENTIFIC PAPER

681.61

DOI: $10.19090 / h k .2019 .3 .41-56$

\title{
SZÉNÁSI Zoltán
}

Bölcsészettudományi Kutatóközpont

Irodalomtudományi Intézete

Budapest, Magyarország

szenasi.zoltan@btk.mta.hu

\section{BABITS MIHÁLY ÉS AZ ÍRÓGÉP - AZ IRODALOM MÉDIUMTÖRTÉNETÉNEK ÖSSZEFÜGGÉSÉBEN ${ }^{1}$}

\author{
Mihály Babits and the Typewriter - in the Context \\ of the Mediology of Literature \\ Mihalj Babič i pisaća mašina - Povezanost književnosti \\ i istorije medija
}

A textológia alapvetően gyakorlatorientált tudományos tevékenység. Mégis magyarországi és nemzetközi példák mutatják, hogy a tudományos szövegkiadással foglalkozó kutatóknak is időnként szembe kell nézniük az irodalomtudományban meghatározó szerepre jutó elméletek kihívásaival. Az alábbiakban a Babits-versek kritikai szövegkiadásának gyakorlati tapasztalata alapján azt vizsgálom, hogy az írógép megjelenése milyen hatással van a versek keletkezésére. Ebben a vizsgálatban Friedrich Kittler mediológiai téziseire támaszkodom. A célom, hogy bemutassam, milyen lehetőségek kínálkoznak a textológia számára a kézírás és a gépírás különbségének leírására. Végezetül pedig irodalomtörténeti nézőpontból arra térek ki, hogy a médiumtörténetben is tetten érhető mechanizáció milyen hatással van Babits gondolkodására, és milyen nyomokat hagy költői világképében.

Kulcsszavak: médium, materialitás, írógép, textológia, kézirat, gép

\footnotetext{
${ }^{1}$ A tanulmány a Bolyai János Kutatási Ösztöndíj támogatásával készült.
} 


\section{Zaj és zajszürés az irásaktus folyamatában - az irásaktusok interpretációja Kittler nyomán}

Friedrich Kittler munkái az utóbbi években Magyarországon is nagy hatást gyakoroltak a kultúratudomány kontextusában újraértelmezett irodalomtudomány mediológiai tájékozódásában. Kittler a maga által művelt irodalomtörténetet határozottan elválasztja a világnézeteket, valamint gondolatépítményeket vizsgáló és az írást mint információs csatornát figyelmen kívül hagyó szellemtörténet, valamint az irodalmat a termelési viszonyok visszatükröződéseként megértő irodalomszociológiától. Ezekkel ellentétben úgy látja: „ha az irodalmi szövegek a történelem, és ha van történelmük, akkor mindez érinti az információs technikák állását programszerüen és nem csak mimetikusan. És ha a költészet hírközlés, akkor technikaként elemezhető ahelyett, hogy [...] elemzése közben alkalomszerüen reflektálnánk más technikákra" (Kittler 2014b, 19). Kittler Aufschreibesysteme 1800/1900 (Lejegyzörendszerek 1800/1900) címü könyvében az irodalmat - Foucault diskurzusfogalmát továbbgondolva - az adott korszak releváns adatainak lejegyzését, tárolását és feldolgozását végző lejegyzőrendszerek részeként értelmezi (Kittler 1990, 369). Míg tézise szerint a klasszikus-romantikus irodalom sikerének anyagi alapját az általános alfabetizáció tette lehetővé, addig az irodalmat is érintő újabb váltás a hang, a kép és az írás rögzítésének és tárolásának technológiai újításaiban határozható meg, a XIX. század utolsó harmadának jelentős találmányai ugyanis - ebből a szempontból - a film, a gramofon és az írógép voltak. „, [A]z irodalom helyi értékét általában változtatta meg az olyan adatfeldolgozó készülékek sorozatgyárthatósága, mint az írógép (az 1878-as Remington II), a fonográf (1887) és a film (1895). Az írás, az akusztika és az optika történetileg soha nem látott módon különül el egymástól" (Kittler 2014b, 23). A három technikai médiumban Kittler az emberi idegrendszer funkcióinak átvételét és - ezzel együtt - az ember gépként való elgondolásának lehetőségét is látja: „Az optika, az akusztika és az írás Gutenberg tároló-monopóliumát 1880 körül szétfeszítő technikai elkülönülésével az úgynevezett ember vált megcsinálhatóvá. Lényege [Wessen] átáll az apparatúrák oldalára. A gépek meghódítják a központi idegrendszer funkcióit, és már nem csupán az izomzatét, ahogy minden gép tette" (Kittler 2014a, 91).

A fonográf által rögzített hangok sorozatát a gramofon szólaltatja meg, míg a kinematográf által felvett képek sorozata a lejátszott filmben válik mozgóképpé. Kittler felhívja a figyelmet, hogy mindkét technikai médium nevében benne található az ,írás”, mint a rögzítés aktusára való hivatkozás. Az írás az ókortól az irodalom médiuma is, mely szintén a rögzítést szolgálja: az alfabetikus 
írás betüi révén a beszéd hangszekvenciáit tárolja (Kittler 2014a, 79), a tárolt információ „megszólaltatása” azonban a kezdetektől nem egy gép, hanem az emberi test és elme együttmüködésével lehetséges, még némaolvasás esetében is. A fonográf és a kinematográf a médiumok anyagi tulajdonságaiból fakadóan nem rögzíti tökéletesen a hangot és a képet, a kép időnként életlen, a rögzíteni kívánt hang mellett zajokat hallhatunk. Kittler gondolatmenetéböl az következik, hogy az írógép le is válik a másik két médiumról, ugyanis szabványosított írásmódjának köszönhetően eleve kiszüri azt, ami a kézírás individuális attribútumait jelentheti. Kittler a Grammophon, film, typewriterben hosszan idézi Heidegger okfejtését az írógéppel kapcsolatban, aki a mechanikus írásban lételméleti fordulatot lát, míg ugyanis a kézírás során közvetlen vizuális és fizikai kapcsolatban van egymással a kéz és az írás hordozójául szolgáló papír, addig az írógép használata megszakítja ezt a kapcsolatot, és a kéz - melynek tudatos használata Heidegger szerint megkülönbözteti az embert az állattól - veszít jelentőségéből az írásaktus folyamatában. „A szabványszövegben szétválik a papír és a test, az írás és a lélek - állapítja meg könyvének bevezetőjében a gépírásról Kittler. - Az írógépek nem tárolnak semmiféle individuumot, betüik nem közvetítenek semmiféle túlvilágot, amelyet aztán a tökéletes alfabéták jelentésként hallucinálhatnának" (Kittler 2014a, 89).

Kittler technikai médiumokra vonatkozó fejtegetései sokban kötődnek Walter Benjaminhoz, különösen A müalkotás a technikai sokszorositás korában címü nevezetes esszéjéhez (vö. Wellbery 2014, 205-206). Habár Benjamin viszonylag kevés figyelmet szentel az irodalomnak, mégis nyilvánvaló a kapcsolat aközött, amit Kittler a kézírás és gépírás különbségéröl Heideggerre hivatkozva állít, konkrétan az individuum eltünése és az auravesztés fogalma között, melyet Benjamin kifejezetten a modern múvészet, mindenekelött a fényképezés és a film kapcsán leír. Nem véletlen, hogy Benjamin nem foglalkozik túl sokat az irodalommal, hisz az a kezdetektől jellemzően sokszorosított formában, idegen kéz által másolva, majd nyomtatva jutott el olvasójához, ezért a „valódiság”, az „eredeti mü Itt és Most-jának” (Benjamin 2019) kérdése az irodalom szempontjából jóval a Benjamin és Kittler által vizsgált technikai médiumok megjelenése előtt másként tevődött fel. Amit egy képzőművészeti alkotás esetében auraként érthetünk - a műalkotás eredeti mágikus-rituális használati és létmódjából fakadóan - a szemlélő profán individuumhoz képest mindig valamifajta szakralitással felruházott művész közvetlen kéznyoma. Szépirodalmi szövegkorpuszokat vizsgálva - s ebben az esetben ismét csak a modernség szövegeiről beszélünk - az auravesztés az autográf kézirat és a belőle készült gépírásos vagy nyomtatott szöveg esetében értelmezhető, noha az eredeti és a 
reprodukció viszonya egészen más, mint a kép vagy a fotó esetében. Miközben vizuálisan szembeötlőbb a különbség az irodalom szövegváltozatai között, a nyomtatott szöveg éppannyira eredeti müalkotásnak számít, mint a kézirat. Az alkotó müvész „,zsenijéhez” kötődő aurát megőrző kézirat azonban egészen más funkciót tölt be, mint a nyomtatott szöveg. Amennyiben a kézirat kikerül az archívum zárt és gondozott teréből, éppen az anyagi hordozóhoz kötődő aura révén az életrajzi múzeum másképpen zárt terébe kerül, és a vitrin üvegén keresztül biztosítja a múzeumlátogató számára a müvész egykori életvilágába, alkotói ihletébe való betekintés illúzióját.

Kérdés persze, hogy mennyire van meg minden esetben az individualitás a kézírásban, és mennyiben tünik el maradéktalanul a gépírásban. Egyrészt a kézírásnak is vannak szabványosított változatai, különösen a nyomtatás széles körü elterjedése és az írógép hivatali használata előtti időszakban. Másrészt az írógép használatának is lehetnek egyéni vonásai, például margószélesség, sortávolság, kis- és nagybetühasználat stb. Diktatórikus rendszerekben, amikor a tiltott szöveg sokszorosítását a hatalom minél inkább vissza kívánta szorítani így például a rendszerváltozás előtti Magyarországon is -, a bünügyi szervek rendelkeztek a megvásárolt írógépek betủmintáival, szükség esetén kriminalisztikai eszközökkel azonosítani tudták az egyes írógépeket. Van filológiai szempontból relevánsabb példája is az írógépek azonosításának. Abban, hogy T. S. Eliot nevezetes műve, az Átokföldje részeinek keletkezési sorrendjét meg tudják állapítani, döntő szerepe volt az egyes részek lejegyzésére szolgáló írógépek pontos azonosításának (Kappanyos 2014).

A zaj, melynek Kittler külön tanulmányt is szentelt (Kittler 2005), tehát a technikai médiumok vizsgálata során nagyon is konkrét jelentésben fordul elö, a kommunikáció materialitásának mellékterméke. Míg a gramofon és a filmvetítő müködése során a gép maga állítja elő a rögzített zajt, addig annak ellenére, hogy a gépírás is zajjal jár, mégis sokkal inkább kiszüri azt a „zajt”, amelyet a lejegyző individuum individualitása visz bele az írásaktusba. Ebben az esetben azonban a zaj már nem szó szerinti, hanem metaforikus értelemben szerepel, de a fogalomhasználatnak erre az átvitt értelmére Kittlernél is találunk példát:

Görög megalapítása óta az volt a költészet funkciója, hogy hangok káoszát címezhető és ezzel artikulált hangokra redukálja, míg a hermeneutika romantikus megalapítása óta - még egyszer, szellemtudományi szempontból biztosította ezt a komplexitáscsökkenést: a Szerző nevü költői alany címének való tulajdonítás révén. Az interpretáció megtisztított egy belső teret minden zajtól, amely viszont minden eseményen túl, önkívületekben és háborúkban nem szünt meg nem megszünni (Kittler 2005, 473). 
Ebben az esetben tehát a Kittler által a némi kétellyel szemlélt hermeneutikai interpretáció tölt be egyfajta „zajszürő” szerepet.

A továbbiakban mindezekből kiindulva, de - a kéz- és gépiratos hagyatékok anyagának rendszerezésére vonatkozóan - ezzel némileg ellentétes értelmezési irányra kívánok javaslatot tenni. Az alkotó individuumát tükröző kézirat írásképe ugyanis gyakran megőrzi azt a hangoltságot, amivel az író lejegyezte gondolatait, más szóval: a kézirat mint íráskép az író lelki diszpozíciójának mint létmódnak a nyomát is magán viseli, mely nyomszerüségében feltárja az író világhoz való aktuális érzelmi viszonyát. Amellett, hogy a műalkotás keletkezésének leírása során eltekinthetünk a romantikus „,ihlet” fogalmától, így tehetünk különbséget a szöveggenezis kezdeti fázisát jelző első fogalmazványok és az elkészült szöveghez közelítő kéziratos tisztázat között is. Példaként Babits kéziratos hagyatékából az [Ó múzsa kínban a többi virággal...] fogalmazványt hozom. A kézirat annak a fóliónak (OSzK Fond III/1969. 10.) a verzóján található, melynek rektóján a Húsvét elött első nyolc sorának variánsa olvasható, a fogalmazványt erős motivikus kapcsolat (,ajakad sebe”, „véres ajak”) köti Babits egyik legismertebb háborúellenes verséhez, olyannyira, hogy a Húsvét elött megszületéséhez kapcsolódó korábbi versötletnek tekinthetjük.

\author{
Ó Múzsa, kínban a többi virággal e szép tavaszon \\ ajakad sebe nyílik a tavaszi széltöl \\ Fakaszd ki énekedet, te véres ajak \\ ha meg kell tenni [?] már \\ de megállj! \\ Borral itatlak elöbb.
}

A kéziratot vizsgálva látható, hogy az első három jambikus lejtésủ sor után, a negyedik sortól a fogalmazvány ritmikailag és motivikusan is szétesik, Babits nem tudja szervesen továbbépíteni az első három sorból kibontakozó versvilágot, a vers zárlata (a múzsa borral itatása) már a versírás közben tudatosuló kudarc tanúsága lehet, s ezt a szétesést valamelyest az elnagyoltabbá váló betüformák révén a kézírás is visszatükrözi.

Egy lap, mely alkalmilag szolgál az író fogalmazványainak gyakran javításokkal teli rögzítésére, esetenként maga az írásban rögzített hangok káosza. A zajszürés első mozzanata ebben az esetben - ha készül ilyen - az autográf tisztázat, mely megőrzi a kézírás individualitását, de szépírás révén igyekszik kiszürni a lejegyző szubjektum érzelmi diszpozíciójából fakadó megértésnehezítő elemeket, mint például a javítások vagy az elnagyolt betüformák. A zajszürés következő vagy másik potenciális lépése - ahogy erre Babits írásgyakorlata is 
példákkal szolgál -, amikor az író vagy egy általa alkalmazott személy írógép segítségével rögzíti a szöveget. A Babits korabeli írógépek billentyüzete azonban még nem tartalmazott minden betüt, ezért a legépelt szöveg, bár megszüntette a kézírás egyéni sajátosságából fakadó „zajosságot”, és az írógép tintája is tartósabban rögzíti az írás nyomát, mint például a ceruza, mégis szükségessé vált az elütésekből fakadó hibák és a hiányzó ékezetek kézírásos pótlása.

Ehhez a problémakörhöz tartozik a szerzőség megállapításának gyakorlati kérdése is, amivel a textológusnak a hagyaték feldolgozása során szintén szembesülnie kell. A kézirat a lejegyzés szubjektív mozzanatai, a tanult betüformák ellenére is egyéni íráskép révén teszi lehetővé a szerzőség azonosítását, de a gépirat esetében, éppen amiatt, mert - ahogy azt fentebb idéztem - a gépírás során elválik egymástól , a papír és a test, az írás és a lélek”, a szerzőség megállapítása is nehézségekbe ütközik. Ha egy gépiratnak létezik autográfja, akkor a mủ szerzőségének kérdése anélkül eldönthető, hogy tisztázni kellene, ki gépelte a szöveget. Ha nem áll rendelkezésünkre ilyen elöszöveg, akkor a gépiraton végzett autográf javítások vagy a szerző saját kezü aláirása segíthet a kérdés tisztázásában. A mü aláírással történő autorizálása a keletkezéstörténetnek is kitüntetett pillanata, ugyanis a magánjellegű feljegyzésekből ezt követően válik (vagy válhat) publikálandó, azaz a nyilvánosság elé tárható szöveg. „,Az aláírás felhatalmaz a sokszorosításra, jogilag a nyomtatási engedélynek felel meg, erkölcsi szempontból pedig általa a szerző felelősséget vállal a leírtakért és sajátjának ismeri el a szöveget. Ily módon az aláírt név választja el az írást a szövegtől, az író személyt az írótól” (Kelevéz 1998, 204). Ha semmilyen autográf rájegyzés nem található a gépirat fólióján, és az adott versnek kéziratos fogalmazványát vagy szerzői névvel ellátott publikált változatát sem ismerjük, akkor a szerzőség kérdéses. Szabó Lőrincnek az MTA Kézirattárában őrzött hagyatékában található [A bús kert orgonát csinál a pusztulásnak...] kezdetű gépirat (MTA Ms 4699. 20.), melyet a kézirat-katalógus Babitsnak tulajdonít, és 1918-19-re datál (Cséve et al. 1993, 31).

A bús kert orgonát csinál a pusztulásnak és néniát zenél:

száz tarló ágon át verebek sípolásznak, s fut s rí a gyáva szél.

Mily olcsó hangital! karcol mint durva karcos! mámortalan zene!

borzongó gyáva dal! borzongó gyáva harcos vérének üteme!

Ó lelkem be ne szállj e gyáva néniába, te is tán harcba mégy!

Állj ha kell, vígan állj a svadronyléniába: katona lelke légy!

A fólión semmilyen autográf rájegyzés sem található, s külön kérdésessé teszik Babits szerzőségét a 4-7. sorok harcra buzdító kijelentései, melyek 
idegenek a háborúellenes Babits gondolkodásmódjától. Vélhetően az ismert életrajzi tény, a költő lelkesedése az őszirózsás forradalom idején bekövetkezett változásokért magyarázhatta a katalógus összeállítói részéről a szerzőség elfogadása mellett az 1918-1919-es datálást, véleményem szerint azonban ebben az esetben kérdéses szerzőségü müről van szó.

\section{Babits íógéphasználata}

„Te, borzasztó passzió ez a gépírás! tanulj meg okv.” - írja levelében a költő szekszárdi barátja 1911. október 25-én (Babits 2003, 49). Talán ennek a biztatásnak is köze volt hozzá, hogy Babits valószínüleg 1914-ben megvásárolta első írógépét (Sára 1983, 402-403). Bár korábban keletkezett verseinek is ismerjük gépiratát, ezek valószínüleg alkalmi vagy későbbi legépelések lehetnek. Mint legfontosabb munkaeszközét Babits az írógépet rendszeresen magával vitte, és úgy tekintett rá, mint egy speciális tudást igénylő szerkezetre, melyet nem kezelhet bárki. Komjáthy Aladárnak 1919 késő őszén írt levelében kiemeli: „Az irógép itt maradt. Szabó Lőrincnek (ha tud vele bánni) megengedheted hogy itt irjon rajta; de semmiesetre sem hogy a lakásból kivigye" (Babits 2012, 25). Tudható, hogy Szabó Lörinc még középiskolásként tanulta meg a gyors- és gépírást, s később Babits írógépét is használhatta (Lengyel 2014). Maga Babits viszont minden bizonnyal autodidakta módon tanulta a gépírást, és amikor nagyobb munkát rövid határidővel kellett legépelnie, akkor hivatásos gépírót alkalmazott. Rédey Tivadarnak írta 1918. május 30-án kelt levelében: „Hozzám ma délután beállit egy irógépes akinek egy egészen sürgős munkát akarok tollba mondani hogy hamarabb kész legyen" (Babits 2011, 89). Változott a helyzet, miután Babits feleségül vette Tanner Ilonát, aki korábban gépírónőként dolgozott, ezt követően legalábbis időnként közös levelezésüket a feleség gépelte. A Szilasi Vilmosnak 1922. február 25-én kelt levelet például egészen biztosan Babits diktálta feleségének², Tanner Ilona utóiratban pedig hozzáfüzi a levélhez: „Az engedelmes gépirókisasszonyi szerepből mint önálló levelező lépek elö, hogy a magam nevében is megköszönjem kedvességüket és a meghivást" (Babits 2014, 156). Talán nem túlzás szimbolikus párhuzamot látni aközött, ahogy Tanner Ilona a diktálást lejegyző gépírókisasszonyból előlép levélíróvá, $\mathrm{s}$ ahogy Kazinczy feleségének nevét felvéve Török Sophie-ként kilép a költö Babits árnyékából.

\footnotetext{
${ }^{2}$ „A feleségemnek diktálom ezt a levelet. Én most lábadozó vagyok, alig szabad mozognom, dolgozni semmit, karlsbadi kurán és diétán élek” (Babits 2014, 154).
} 
Kittler Grammophone, film, typewriter címü könyvében több példán is illusztrálja, hogy egyes alkotók esetében a kézírásról a gépírásra történő átállás hogyan hagyott nyomot írásmüveikben (Kittler 1999, 216). Nem ismerek olyan interpretációs kísérletet, mely Kittlerhez hasonlóan az írógéphasználat hatását értelmezné Babits írásmüveiben, pedig erre maga az író ad szempontot számunkra a Halálfiairól tett nyilatkozatának zárlatában: „Egy vén fotőjben ülve messze beláttam a drága dombokat, s írógépem kattogását bizonyára kereplö hangjának vélték a szőlőt csipkedő madarak. Talán lehet majd valamit érezni mesém pergésében a hegyi kereplő szabad üteméből, rajzom színeiben az édes táj színéből...” („Babits Mihály nyilatkozik a Halálfiairól” 1927, 10). Egy kellően szubtilis szövegelemzés talán be tudná mutatni a keletkezés körülményeinek hatását a regény narrációjában, jelen tanulmány azonban erre nem vállalkozhat.

Elgondolkodtató viszont, hogy az írógépvásárlás nagyjából egybeesik azzal, hogy Babits végleg befejezi az Angyalos könyv vezetését, az utolsó autográf versbejegyzések 1912 tavaszára datálhatók, de még a harmadik füzetbe írja A literátor címü Kazinczyról szóló drámáját, melynek keletkezési ideje 1916 öszére tehető (Kelevéz 1998, 262-263). Babits textológiai elveit és költői gyakorlatát vizsgáló tanulmányában Kelevéz Ágnes megállapítja, hogy a 10-es évek közepétől

verseit általában már gépiratos formában adja le a nyomdának, és ilyen módszerrel sokszorosítja is őket. Természetesen a gépiratokon sokszor látunk javítást, főleg az ékezetek tekintetében, de általában az már a vers tisztázata, melyet a gépbe ír, agyonfirkált és többször átgépelt költeményt nemigen találunk. A tízes évek közepétől tehát egészen világosan elválik egymástól a versek hevenyészett fogalmazványa és a leadásra szánt korrekt tisztázat (leggyakrabban gépirat) (Kelevéz 1998, 26).

A költői szerepváltások kéziratos nyomainak elemzése során Kelevéz is a jól olvasható, mindig magánál tartott autográf tisztázatok háttérbe szorulását Babits kéziratos hagyatékában összefüggésbe hozza az írógép használatával (Kelevéz 1998, 225). Az írógép megvásárlása tehát hasonló fordulatot jelent költői pályáján ahhoz, mint ahogy az európai kultúrtörténetben a Gutenberg mozgatható betükkel müködő nyomdájában készült könyv idővel felváltotta a kézzel írt kódexet. Ahogy azonban a könyvnyomtatás sem törölte el egyik pillanatról a másikra a kódexkultúrát, úgy a költői írásaktusban is végig megmaradt a kézírás szerepe, de - ahogy arra Kelevéz Ágnes is utal - egyfajta funkciómegoszlás figyelhető meg: míg a fogalmazványok továbbra is kézírással készülnek, 
a tisztázatok többnyire már gépiratok. ${ }^{3}$ 1928-ban tett nyilatkozatában ugyan Babits saját munkamódszerét ismertetve azt állítja: a fejében kész mondatokat azonnal gépbe írja (Bisztray 1928), ennek azonban ellentmond, hogy ebböl az időszakból is több ceruzaírású fogalmazvány maradt fenn.

\section{Gép és gépiesség Babits írásaiban}

Tudható, hogy Babits fogékony volt az új technikai médiumok iránt, 19061907 körül például verset írt Mozgófénykép címmel a mozifilmröl, melyet Füzi Izabella egyenesen „a filmről és a mozihatásról szóló nyelv, diskurzus egyik alapító darabjának" tekint (Füzi 2016), A gólyakalifának pedig filmadaptációja is készült nem sokkal a regény megjelenése után Karinthy Frigyes átdolgozásában. Babits azonban nemcsak szórakozási lehetőséget, vagy műveinek ihletforrását látta a filmben, hanem a tudás hagyományos hordozójára, a könyvre s ezáltal a klasszikus európai müveltségre leselkedő veszélyként is érzékelte a XIX-XX. század fordulójának médiumtörténeti váltását, azt ahogy - erre a fentebb idézett könyvében Kittler is utal - a gramofon, a film és az írógép megtöri „Gutenberg tárolómonopóliumát". Az Elza pilóta disztópiájában Schulberg a következőképpen mutatja be az Örök Harc korának könyvtárát: ,- Ez is könyvtár - mondta. A szobában gramofon volt, és mozigép, és lemezkorongok, és filmtekercsek, és rádió, és televizor. - Ez a mai könyvtár, az aktuális, a szemét... Itt az agitatív korongok, itt a technikai filmek... Itt a szórakoztató... Ezen a téren a cenzura, úgy látszik, csak butaságokat engedélyez" (Babits 2002, 142).

Tágabb összefüggésben vizsgálva a témát, megállapíthatjuk, hogy a XX. század első felének indusztrializált társadalmában a gép használata alapvető tapasztalata volt Babitsnak is, a gépiesség, a gépszerüség általában negatív motívumként vagy jelzőként szerepel verseiben és esszéiben. A Húsvét elöttben a gép mint a pusztítás eszköze jelenik meg, később Az irástudók árulásában így foglalja össze ennek konklúzióját: „A tudomány az Élet harcainak szolgája lesz, iszonyatos szolga, emberirtó háborús masinák gépésze" (Babits 1978b, 225). 1932-ben megjelent $A$ másik Amerika címú írásában Amerika ipari társadalma egy negatív jövő előképét mutatja számára: „A Duhamel gépországa, egy naiv nagyüzem, egy grandiózusan sivár jövendő előrevetett árnyéka, rettentő kilátás, az állatember praktikus életének végképp megszervezett formája, a demokrácia végső konklúziója” (Babits 1978a, 345). Tanulságosak továbbá a

3 Kötetek összeállításánál a kézírásos tisztázat és a gépirat mellett megfigyelhető egy harmadik szövegtípus használata is: a már megjelent vers kivágata, rajta gyakran autográf javításokkal. 
géppel kapcsolatos kifejezések metaforikus használatai is. Dante fordításáról értekezve a tercinák ihletett, egyetlen lehetséges fordításával szembe a „lelketlen gép pontosságá”-t (Babits 1978c, 269) és a „megszokásból eredő gépies könnyüség"-et (Babits 1978c, 273) állítja, Ágoston kapcsán pedig az igazságosságot és a szabadságot az immanens tények ,kegyetlen és gépszerủ okozati láncolatá"-n (Babits 1978, 494) kívülre, a térben és időben adott világ határain túlra helyezi. Világosan szétválik tehát Babits gondolkodásában az immanencia elembertelenítő, elgépiesítő világa a Szellem és Humanitás transzcendens értékvilágától, és egyértelműen ez utóbbi kap részéről pozitív értékindexeket.

Shakespeare egyéniségéről értekezve 1909-ben a fényképezőgépet használja hasonlatként a világérzékelés sokféleségének szemléltetésére (Babits 2010b, 208-209), de Kittler felöl olvasva még inkább figyelemre méltó, amit Bergson filozófiájának ismertetésekor 1910-ben az idegrendszerről ír: „Az idegrendszer tehát nem egyéb, mint egy energiát felhalmozó s aztán továbbadó (vagyis mozgató) gép, amely a szabad életnek rendelkezésére áll, s annak szabad hatását komplikáltsága arányában biztosítja. Az érző idegek beviszik az energiát, a mozgató idegek ismét kiviszik" (Babits 2010a, 333). Az élet örök változásával szemben az idegrendszer az emberben tehát csak az anyagisághoz kötődő, mozgásokat közvetítő gépezet, melynek mechanikus müködése miatt válik nevetségessé az ember. Az idegrendszer müködésének ez az interpretációja teszi lehetővé egyrészt az idegrendszeri funkciók (mozgás, hang- és fényérzékelés stb.) gépekkel történő helyettesítését, másrészt pedig az ember gépként való elgondolását is. Babits számára humanizmushite ellenére is adott volt tehát a gondolat - ha talán nem is Nietzschétől jutott el ide, miként Kittler (Kittler 1999, 188) -, hogy az embert magát is gépként képzelje el. Egy Babits életében kiadatlan, valószínúleg 1920 körül keletkezett, avantgárd hatást is tükröző kéziratos vers (MTA Ms 4699. 29.) egyértelmúen megfogalmazza a szubjektum hasadtságának, az énnek önmagától való elidegenedését, és ezzel együtt a lélekben lakozó másik emberi attribútumoktól való megfosztottságában gépként történő érzékelését:

Künn kacag enyhe, tarka nyár

de bellül a szigoru tél nyög

agyamba mar és kalapál

szigorral egy iszonyu mérnök

ó rettenetes ez a tél

vonalakkal egyszinü tábla

ó zsarnok és rab aki mér

iszonyú a sivatag ábra
Különös, belső mérnök ez esze van, de mégis gép csak vakon kalapál és szögez és minden ötlete jégcsap Én, vagyok, mégis idegen lélek, noha lelke nincsen s bár puszta eszközöm nekem ö tart iszonyú bilincsben 


\section{Az irógép mint ,„diskurzusgépfegyver” Babits verseiben}

Babits életmüvében más példákat is találunk arra, hogy a mediatizált világ szinkrón tapasztalata Kittler történeti analíziséhez hasonló eredményekre vezet. Az 1932-ben írt Verses napló ciklusának (Négy óra felé) című darabjában olvashatjuk:

Nyilt irógépemen leüllepszik a por.

Nem furcsa-e, kedves, igy idehuzódva

élni (s tán egy kicsit táblabirómódra)

egy irógéppel, mint tört vitéz egy rokkant gépfegyverrel: aki elmaradt egy dombon s messze látja hogy a barbár ellenerő mindent befon, nincsjog, s a kuszára görbedt igazságtalanság fölveri a völgyet -

Kittler abból a történeti tényből kiindulva, hogy a Sholes által kifejlesztett írógép sorozatgyártását a polgárháború után forgalomhiánnyal küzdő, eredetileg fegyvergyártással foglalkozó Remington cég indítja el, Scholes találmányát „diskurzusgépfegyvernek” (Diskursmaschinengewehr [Kittler 1986, 283]) nevezi, jelezve ezzel az írógépnek a korabeli lejegyzőrendszerek átalakulásában játszott szerepét. Babits verse - megidézve a hét évvel korábban keletkezett A gazda bekeriti a házát címú verset is - természetesen más összefüggésben nevezi az írógépet „gépfegyvernek”, hiszen a hétköznapi élethelyzetben láttatott költő saját szerepértelmezését árnyalja ezzel, a barbársággal vívott küzdelemben való vesztes helyzetét szemlélteti, mégis - azt gondolom - a Kittlerével azonos szóválasztás szemléletbeli rokonságot is mutat.

1926. július-augusztus körül született, és $A z$ Est augusztus 20-i számában jelent meg az Írógép elött címü prózaverse, mely Babitsnak az írógéppel történő írásaktusra vonatkozó felfogása szempontjából rendkívül tanulságos.

Most eleresztem ujjaimat az írógép billentyüin, és nézem, mit írnak? Szaladjatok, kis csikók, szaladjatok! Az alaktalan márványtömbben szobrok rejtőznek... a legszebb szobrok, minden szobor... csak ki kell fejteni. Így rejti magában az írógép billentyüzete is a legcsodálatosabb költeményeket - vigyázzatok, ti csodálatos ujjak, micsoda sorrendben ütitek le őket!

Óh milyen nagy, különös, veszedelmes dolgok bújhatnak itt - mennyi felelősség van rajtatok, ti könnyelmü ujjak! Csak egy csekélyke sorrendkülönbség, és amit leírtok, tán egy megbotránkoztató trágár szó lesz... vagy talán az a szó... a tilos varázsszó, amely megadja a Lét Kulcsának rejtélyét. Most figyelem! ezt a betüt itt ki kell hagyni, mert különben az egész értelem megváltozik... az egész értelem ostoba lesz vagy hökkentő vagy nevetséges... Mi lenne, ha egyszer csakugyan egészen szabadon eresztenélek benneteket?... 
Oh, bizonnyal semmi - csak értelmetlenség, megzavart betük futkosása, őrült szavak Agramas-tábora... mert mik vagytok ti magatokra hagyva, vad eleven ujjak? Ostoba ösztönök játékai, az emberi állat életének játékai, aki oly tehetetlen, ha kézenfogva nem vezeti a Világürnek ama személytelen s géplábú lakosa: az Ész. Vagy talán, mint mondják manapság, akkor bölcs igazán, s ti se tehettek jobbat, elszabadult ujjak, minthogy vaktában s ösztönötök szerint értelmetlen vagy trágár szókat vertek, vagy talán valami bolond indulatban megfojtjátok azt, akit szerettek?

Mit rejtesz magadban, te szörnyű gépecske, ami nem esik az Észnek útjába? Talán a Legnagyobbra, Legfélelmesebbre, ami tebenned van, csak a Véletlen szörnyü mozdulata tapinthat rá?

Már este van, s kint ülök a terrászon, köröttem a világ, alattam a város, félkörben mint egy óriás billentyüzet... azon pedig az Isten ujja ír! Ír, ír, türelmesen, fáradhatatlanul; az ő ujját bizonnyal nem az ész vezeti. Az ész a gépben van és nem az ujjakban; én s te a gépben vagyunk, s ti, kik ujjaknak vélitek magatokat, csak billentyük vagytok.

Láttam billentyüket, kik égi olajért imádkoztak, és láttam billentyüket, kik nem tudták, mily szavakhoz kellenek?

A vers nyitó mondata az írásaktus szinkrón folyamatában szétválasztja egymástól a gépírást végző kezet, az írásaktust vezérlő tudatot, valamint a rá irányuló tekintet megjelenítése révén magát az írást. Babits egy képzőmüvészeti analógiával Michelangelót parafrazeálva világítja meg az írói alkotótevékenységet: úgy, ahogy minden márványtömbben már benne van a legszebb szobor lehetősége, úgy az írógép is magában rejtheti a legcsodálatosabb költeményeket, csupán le kell ütni a megfelelő billentyüket. Tudat és test különválasztása azonban az írásaktusban vétett hiba, az elütés révén jelölő és jelölt viszonyának, a betű jelentés-megkülönböztető szerepének önreflexív újragondolása felé nyitja meg a vers gondolatfutamait. A betü kiemelése a jelentésképzésben szintén összefüggésben van az írógéphasználattal, mivel amíg a kézírásban az írásaktus alapegysége a szó, addig ez a gépírásban a többi betűtől térbelileg is elkülönülö betü. A fonémát jelölő, klaviatúrán leütött betü tehát kétszeresen is a hiányt jeleníti meg: egyrészt - a strukturalizmus nyelvfelfogását követve - a nyelv természetes müködésében benne rejlö differencia révén, ami a fonémákat egymástól megkülönbözteti, másrészt a tudati kontroll hiánya miatt, mely jelölő és jelölt kötött viszonyának fellazulásával fenyeget: „Mi lenne, ha egyszer csakugyan egészen szabadon eresztenélek benneteket?... // Oh, bizonnyal semmi - csak értelmetlenség, megzavart betúk futkosása, őrült szavak Agramas-tábora...” 
Babits versében benne rejlik egy lényeges párhuzam „a végtelen majom lemmájaként" emlegetett elméleti tétellel (Szűts 2013,31-35). A tételnek többféle megfogalmazása ismert, lényege, hogy végtelen számú majom az írógép billentyüzetét véletlenszerüen lenyomva idővel biztosan leírja Shakespeare vagy éppen a világ valamennyi remekmúvét. Ez a gondolatkísérlet Babits korában is ismert volt, félig-meddig irodalmi példaként Borges 1939-es The Total Library címủ írását említhetjük, vagy Arthur Eddington brit fizikus a The Nature of the Physical World címü könyvét, aki 1927-ben Babitshoz egészen hasonló felütéssel fogalmazta meg ezt a tételt:

Ha hagynám az ujjaimat hanyagul vándorolni az írógép billentyüin, akkor megtörténhetne, hogy idővel értelmes jelentésü mondatokat kapok. Ha egy sereg majom kalimpálna az írógépen, akkor megírhatnák a British Museum összes könyvét. Ennek a lehetősége határozottan nagyobb, mint annak a lehetösége, hogy a molekulák az edénynek ugyanabban a felében gyüljenek össze (Eddington 2014, 82).

A majom ebben a statisztikai tételben a tudat nélkül múködő gépet jelképezi, mely, ha rendelkezésére áll elegendő idő, végső soron képes értelmes szavak, szövegek elöállítására. Babits verséhez ezt a tételt a véletlenszerủen elöállított értelem gondolata füzi, mely a költő számára inkább fenyegetést, semmint lehetőséget jelent: „Mit rejtesz magadban, te szörnyü gépecske, ami nem esik az Észnek útjába? Talán a Legnagyobbra, Legfélelmesebbre, ami tebenned van, csak a Véletlen szörnyü mozdulata tapinthat rá?"

Az Írógép elött gondolatmenete - hasonlóan ahhoz, ahogy azt például az Eddingtontól vett idézetben is láthatjuk - túllép ezen az elvi tapasztaláson, a gépírás a világ müködésének modelljévé válik. A prózavers ötödik szakaszában a gépírás-aktus és annak materiális előfeltétele, az írógép alaki hasonlósága révén válik az adott világdarab (a költö környezete, az esztergomi Előhegy) és a világot alkotó, alakító Isten analógiájává. Hasonló poétikai mozzanatot figyelhetünk meg tehát, mint a két évvel korábbi Ádáz kutyámban, a transzcendens létező megérthetetlenségének problematikája azonban itt talán még radikálisabban fogalmazódik meg, amennyiben az ,isteni írásaktust” vezetö, és az emberi ész számára felfoghatatlan értelmet nem az Istenhez, hanem - visszautalva a nyitó szakasznak az írógépben benne rejlő mủalkotásokra vonatkozó gondolatára - a mechanikus gépként láttatott világhoz köti. A vers így végül az emberi egzisztenciára vonatkozó kételyek megfogalmazásával zárul.

A fentebbiekben kurrens irodalomtudományi nézőpontból, a szöveg materialitása és medialitása felől kívántam felvetni új kérdéseket, melyek 
egyrészt termékenyen építenek a kéz- és gépiratos hagyaték feldolgozásának mindennapi gyakorlatára, másrészt új szempontokat adhatnak a vers keletkezéstörténetének vizsgálata során rekonstruálható írásaktusok megértéséhez és leírásához is. A technikai médiumok poszt-hermeneutikus vizsgálata reményeim szerint nemcsak a textológiai gyakorlat számára lehet megtermékenyítö, hanem Babits életmüvének értelmezéséhez is új szempontokat adhat azáltal, hogy az irodalom medialitásának életmüben reflektált problematikáján keresztül korábban kevesebb figyelmet kapó müvekre irányítja a figyelmet.

\section{Irodalom}

Babits Mihály. 1927. Nyilatkozik a Halálfiairól. Pesti Napló, ápr. 9. 10.

Babits Mihály. 1978. Ágoston. In Uỏ. Esszék, tanulmányok. 1. kötet. Sajtó alá rendezte Belia György. 472-498. Budapest: Szépirodalmi Kiadó.

Babits Mihály. 1978a. A másik Amerika. In Uő. Esszék, tanulmányok. 2. kötet. Sajtó alá rendezte Belia György. 345-348. Budapest: Szépirodalmi Kiadó.

Babits Mihály. 1978b. Az írástudók árulása. In Uő. Esszék, tanulmányok. 2. kötet. Sajtó alá rendezte Belia György. 207-234. Budapest: Szépirodalmi Könyvkiadó.

Babits Mihály. 1978c. Dante fordítása: Mủhelytanulmány. In Uő. Esszék, tanulmányok. 1. kötet. Sajtó alá rendezte Hibsch Sándor-Pienták Attila. 269-289. Budapest: Szépirodalmi Kiadó.

Babits Mihály. 2002. Elza pilóta vagy. Sajtó alá rendezte Buda Attila. Budapest: Magyar Könyvklub.

Babits Mihály. 2003. Babits Mihály levelezése: 1911-1912. Sajtó alá rendezte Sáli Erika. Budapest: Magyar Könyvklub.

Babits Mihály. 2010a. Bergson filozófiája. In Uö. Esszék, tanulmányok, kritikák: 1900-1911. Sajtó alá rendezte Hibsch Sándor-Pienták Attila. 324-349. Budapest: Argumentum Kiadó.

Babits Mihály. 2010b. Shakespeare egyénisége. In Uő. Esszék, tanulmányok, kritikák: 1900-1911. Sajtó alá rendezte Hibsch Sándor-Pienták Attila. 206-232. Budapest: Argumentum Kiadó.

Babits Mihály. 2011. Babits Mihály levelezése: 1918-1919. Sajtó alá rendezte Sipos Lajos. [Budapest]: Argumentum Kiadó.

Babits Mihály. 2012. Babits Mihály levelezése: 1919-1921. Sajtó alá rendezte Majoros Györgyi-Tompa Zsófia. [Budapest]: Argumentum Kiadó.

Babits Mihály. 2014. Babits Mihály levelezése: 1921-1923. Sajtó alá rendezte Szőke Mária. A jegyzeteket írta Sipos Lajos. Budapest: Argumentum Kiadó. 
Benjamin, Walter. A múalkotás a technikai reprodukálhatóság korában. http://aura. c3.hu/walter_benjamin.html (2019. szept. 26.)

Bisztray Gyula. 1928. Négyszemközt Babits Mihállyal. Az Ellenzék Melléklete, máj. 7. 1. Cséve Anna-Kelevéz Ágnes-Melczer Tibor-Nemeskéri Erika-Papp Mária szerk. 1993. Babits Mihály kéziratai és levelezése: Katalógus. Budapest: Argumentum Kiadó-Petőfi Irodalmi Múzeum.

Eddington, Arthur Stanley. 2014. The Nature of the Physical World: Gifford Lectures of 1927. Newcastle upon Tyne: Cambridge Scholars Publishing.

Füzi Izabella. 2016. Babits és a korai (magyar) mozi. Apertúra website http://uj.apertura. hu/2016/tel/fuzi-babits-es-a-korai-magyar-mozi/ (2019. szept. 26.)

Kappanyos András. 2014. Egy filológiai regény vége. Holmi 26 (11): 1368-1384.

Kelevéz Ágnes. 1998. A keletkező szöveg esztétikája: Genetikai közelités Babits költészetéhez. [Budapest]: Argumentum Kiadó.

Kittler, Friedrich. 1986. Grammophon, film, typewriter. Berlin: Brinkmann\&Bose.

Kittler, Friedrich Adolf. 1990. Discourse networks 1800/1900. Ford. Michael MeteerChris Cullens. Stanford, California: Stanford University Press.

Kittler, Friedrich Adolf. 1999. Gramophone, Film, Typewriter. Ford. Geoffrey WinthropYoung-Michael Wutz. Stanford, California: Stanford University Press.

Kittler, Friedrich. 2005. Jel és zaj távolsága. Ford. Lőrincz Csongor. In Bónus TiborKelemen Péter-Molnár Gábor Tamás szerk. Intézményesség és kulturális közvetités. 454-474. Budapest: Ráció Kiadó.

Kittler, Friedrich. 2014a. Gramofon - film - írógép. Ford. Tóth-Cifra Júlia. Prae 15 (4): 74-94.

Kittler, Friedrich. 2014b. Lejegyzőrendszerek 1800/1900: Előszó. Ford. Zsellér Anna Prae 15 (4): 19-34.

Lengyel András. 2014. Írógép, írás, irodalom: Az írógéphasználat magyarországi történetéhez. Kalligram 23 (2): 78-94.

Sára Péter. 1983. Babits legkedvesebb tárgyai közt. In Kelevéz Ágnes szerk. Mint különös hírmondó: Tanulmányok, dokumentumok Babits Mihály születésének 100. évfordulójára. 389-404. Budapest: Petőfi Irodalmi Múzeum-Népmüvelési Propaganda Iroda Kiadó.

Szüts Zoltán. 2013. A világháló metaforái: Bevezetés az új média müvészetébe. Budapest: Osiris Kiadó.

Wellbery, David E. 2014. Előszó (a Lejegyzőrendszerek 1800/1900 amerikai kiadásához). Ford. Keresztes Balázs Prae 15 (4): 183-206. 


\section{MIHÁLY BABITS AND THE TYPEWRITER - IN THE CONTEXT OF THE MEDIOLOGY OF LITERATURE}

Textology is fundamentally a practice-oriented activity. Yet, examples from Hungary and the world show that researchers involved in scholarly text editing have to face the challenges of dominant theories in literary studies from time to time. On the basis of practical experiences in critical editing of Babits's poems, I examine in the following the impact the typewriter had on the creation of poems. In this analysis I rely on Friedrich Kittler's mediological theses. My purpose is to demonstrate the opportunities available to describe the differences between typewriting and handwriting. Finally, from the perspective of literary history I mention the effects and traits of mechanization - also present in mediology - on Babits's thinking and poetic worldview.

Keywords: medium, materiality, typewriter, textology, manuscript, machine

\section{MIHALJ BABIČ I PISAĆA MAŠINA - POVEZANOST KNJIŽEVNOSTI I ISTORIJE MEDIJA}

Tekstologija je u osnovi praktično orijentisana naučna disciplina. Ipak, mađarski i internacionalni primeri ukazuju na činjenicu da se i istraživači koji se bave objavljivanjem naučnih radova povremeno moraju suočiti sa teoretskim izazovima u nauci o književnosti. U ovom radu se na osnovu praktičnih iskustava vezanih za kritička izdanja Babičevih stihova razmatra kakav uticaj je imalo pojavljivanje pisaće mašine na nastanak njegovih pesama. U analizi se polazi od medioloških teza Fridriha Kitlera. Cilj rada je da predstavi mogućnosti tekstologije prilikom opisivanja razlika u stvaranju rukopisa i u pisanju mašinom. Na kraju se iz književnoistorijske perspektive daje osvrt na pitanje kakav je uticaj imalo pojavljivanje mašine na Babičev način razmišljanja i kakve je tragove ostavilo u njegovoj pesničkoj slici sveta. Ključne reči: medij, materijalnost, pisaća mašina, tekstologija, rukopis, mašina 